\title{
Dilemma of Third World Countries - Problems Facing Pakistan Energy Crisis a Case-in-Point
}

\author{
Muhammad Tahir Masood (Corresponding author) \\ Professor, Department of Management Sciences \\ COMSATS Institute of Information Technology, Islamabad, Pakistan \\ Tel: 92-342-552-2342 E-mail: dr.tahirmasood@comsats.edu.pk
}

Fawad Shah

CEO, 3EZ Consultant, Lahore, Pakistan

E-mail: fawad_shah24@yahoo.com

Received: September 30, 2011

Accepted: December 20, 2011

Published: March 1, 2012

doi:10.5539/ijbm.v7n5p231

URL: http://dx.doi.org/10.5539/ijbm.v7n5p231

\begin{abstract}
Developing countries of the world are facing enormous problems and Pakistan is no exception. Pakistan is a developing country in South Asia which is the fourth largest populated country in the region and sixth largest country in the world. This study on Pakistan is a case-in-point for other developing nations of the world. So, it is important to highlight these problems including the energy crisis which has assumed serious dimensions during the last three to four years. Pakistan is facing serious problems in almost all the sectors, but energy problem has impacted the economic development severely. Apart from identification of the problems being faced by Pakistan, the paper focuses on the public perception and suggestions to solve them. Lack of governance, corrupt leaders, inadequate and faulty planning, and non-availability of speedy justice are the most critical of a long list of problems being faced by Pakistan. Pakistan is facing energy crises in the shape of Supply /Demand gap, Interrupted Supply, Energy losses, Energy Conservation, Quality of Energy Resources, Quality of energy services, inefficient appliances, Lack of infrastructure, Deforestation, Environmental issues, Health issues, Low BTU value, opportunity cost, fertilizer issues, Renewable and Nuclear Energy Promotion issues, etc. In the paper, relevant conclusions are drawn to suggest some solutions.
\end{abstract}

Keywords: Developing countries, Energy crisis, Pakistan's problems, Economy, Lack of governance, Unemployment, Load-shedding, Power generation, Hydel, Natural gas issues, Safety issues, Over-population, Corruption

\section{Literature Review}

We start the literature review with international reviews of some articles related to energy economic scenario: Comstock, Owen and Boedecker, Erin (2010). Standards, subsidies, and carbon taxes are among the measures often considered to reduce energy consumption and carbon dioxide ( $\mathrm{CO} 2)$ emissions in the buildings sector. Using a modeling system developed by the U.S. Energy Information Administration, residential and commercial sector standards and subsidies were each modeled with and without a carbon tax to determine if a multi-policy approach would be redundant.

Giraudet, Louis-GaÃ«tan, et al. (2010). The authors in their paper assess the impact of French policies for residential space-heating energy consumption, both enacted (tax credits for the purchase of energy efficient durables, soft loans for retrofitting actions, stringent building codes) and anticipated (carbon tax, retrofitting obligation). It uses a hybrid energy-economy model incorporating specific features of energy conservation, notably the rebound effect and some "barriers" to energy efficiency such as split incentives and imperfect information.

Gravin, Jr., Clifton C., (1983). It is understandable that, after a decade of oil worries, consumers and their governments should find joy in today's oil market. According to Department of Energy data, the real cost of a 
barrel of internationally traded oil has fallen somewhere between 25 and 40 percent over the past two years. While this poses problems for the international banking community and a number of oil-producing nations, most experts are convinced that for the world as a whole it means higher economic growth and lower inflation.

Hoicka, Christina E. and Parker, Paul (2011). Since 1999, the Residential Energy Efficiency Project, through Green Communities Canada, has been a delivery agent for EnerGuide for Houses and ecoENERGY programs in the Waterloo Region. This research analyzed 10,208 initial and 2,383 final evaluations made by the Residential Energy Efficiency Project between May 1999 and February 2009 to understand what energy efficiency improvements homeowners have made over time.

Kou, Bing'en (2009). China is in the process of industrialization and electricity is indispensable for rapid growth. At the same time, the "coal-based" energy structure in China will not change perennially, which means, the development of power industry will be subject to the constraints of resources and environment for a long period of time. Therefore, according to the development of electric power industry, energy saving and emission reduction will be an eternal theme.

$\mathrm{Li}$, Lan (2010). In Li's paper, the relation between the energy consumption and the export of Shandong is analyzed by co-integration and Granger causality test. The research result as follows: there is a positive relationship between the export and energy consumption. On the other hand, the growth of the export is cause of increase of the energy consumption. Therefore the increase of Shandong's export promotes energy consumption and also is restricted by its energy consumption.

Mundaca, Luis, et al. (2010). The growing complexities of energy systems, environmental problems, and technology markets are driving and testing most energy-economy models to their limits. To further advance bottom-up models from a multidisciplinary energy efficiency policy evaluation perspective, we review and critically analyze bottom-up energy-economy models and corresponding evaluation studies on energy efficiency policies to induce technological change. We use the household sector as a case study. Our analysis focuses on decision frameworks for technology choice, type of evaluation being carried out, treatment of market and behavioral failures, evaluated policy instruments, and key determinants used to mimic policy instruments.

Sovacool1, Benjamin K. and Brown, Marilyn A. (2010). How well are industrialized nations doing in terms of their energy security? Without a standardized set of metrics, it is difficult to determine the extent to which countries are properly responding to the emerging energy security challenges related to climate change: a growing dependency on fossil fuels, population growth, and economic development. In response, this article first surveys the academic literature on energy security and concludes that it is composed of availability, affordability, efficiency, and environmental stewardship. It then analyzes the relative energy security performance, based on these four dimensions, of the United States and 21 other member countries of the Organization for Economic Co-operation and Development (OECD) from 1970 to 2007. Four countries are examined in greater detail: one of the strongest (Denmark), one of the most improved in terms of energy security (Japan), one with weak and stagnant energy security (United States), and one with deteriorating energy security (Spain).

Takahashi, Masahito and Asano, Hiroshi (2010). Building sector is the highest growing sector in energy demand in Japan at present. There is a strong need to reduce this sectoral energy demand to achieve the national carbon emission target.

Wu, Funfang and Guan, Lei (2009). The Inner Mongolia Autonomous Region of China possesses abundant primary energy sources, and the quick developments of coal and electric power industry have established stable base for the high-speed growth of the economy of the autonomous region. Under the premise that the Inner Mongolia region pushed the electric power market oriented reform and established the electric power trading market, the basic principles to construct the electric power market in Inner Mongolia were discussed, and the market mode, market characters, market subject and trading mode in various phases of the grading reform were designed, and the trading type and the trading flow of the present reform phase were described in detail in the article.

Yuan, Mei (2010). In an effort to compare the effectiveness of possible policy options to tackle a range of energy and environmental issues, we employ an integrated assessment model which couples a technology-rich bottom-up model of the U.S. electricity sector with a fully dynamic forward-looking general equilibrium model of the U.S. economy. The model provides a unique and consistent modeling framework for energy and environmental policy analysis. Though energy efficiency standards are found to be the least cost-effective at reducing energy usage or mitigating carbon emissions, their appeal is likely to rest on assumptions about specific market failures or on political factors. 
Next we identify energy crisis opinions in Pakistan: When you have to shoot, shoot. Don't talk. The Good, The $\mathrm{Bad}$, and the Ugly. Faithlessness and lack of competent leaders are the main problem. In my view the main problem of Pakistan is lack of complete resources, when we have lack of resources we try to get them illegally, then it creates corruption and you know corruption. Pakistan is facing multifarious problems in modern times such as leadership vacuum, absence of proper planning, weak institutions, low F.D.I., trust deficit (in all aspects), power crisis (load shedding), unemployment, torn national image, poverty(mother of all problems), food crisis, extremism, low literacy rate and the list goes on and on..... but the biggest of all problems is that no one is ready to take the responsibility, everyone is looking for scapegoat. Undoubtedly it is high time that each one of us should take his/her responsibility to save the country because there is no use of sweeping the dust under the carpet. Late Prime Minister of Pakistan Benazir Bhutto Shaheed said, "You can imprison a man, but not an idea. You can exile a man, but not an idea. You can kill a man, but not an idea" (CSS Forum, 2009).

Energy Crisis leaves Pakistan textiles in tatters: Power cuts sometimes lasting more than 12 hours a day have forced factory owners in the country's cloth capital Faisalabad to switch off the lights and sell their looms for scrap, leaving tens of thousands of workers jobless. The country is the world's fourth-largest producer of cloth and the industry accounts for 60 percent of export revenue according to official data. But the shortages are heaping pressure on Pakistan's crippled and debt-ridden economy (Atif, 2011).

Islamic Republic of Pakistan, a country of 170 million people, full of natural resources and more than 60 years of independence but still not respected in the world community. In less than 30 years of independence, it's one wing gets separated (Bangladesh). Remaining part till today is living on IMF, World Bank and foreign donations. Majority of the population is living in rural areas without basic necessities of life. It is a country where financial gap between rich and poor is widening day by day. From the last 10 years, extremism is increasing. Whatever happens in the world it is almost understood even before investigations that it will have a link with Pakistan. Almost every kind of problem exists in Pakistan, including electricity load-shedding, bad economy, less educational facilities, less hospitals, inflation and no pure water in many parts. These problems exist in Pakistan right from its independence which as mentioned above was more than sixty years ago. Thus in these 60 years, why our beloved country is not among developed nations even with so many natural resources? Like China, it got independence after us and is now a super power in the world. Like Japan whose major cities were bombed to ashes and has no natural resources but still today they are world economic power. If one would think about the reasons for the problems which Pakistan is facing today, there are numerous. But above all is one. i.e., politicians. "Do our politicians represent our people"? In a democratic system, the elected people should represent the nation so that nation should have faith on their decision. They should think for the betterment of their people and country. In case of Pakistan, look at our politicians. Majority of them are only interested in securing their seat in national assembly through any means. Many of them have criminal cases on them. And above all, there are people who cheated constitution of Pakistan but still are part of parliament. It looks like the more corrupt you are, the more you will have chances of being a parliamentarian (Pakistan Tribune, 2010).

Nuclear Power in Pakistan. Yes or No? Pakistan's Economy is in Intensive Care right now. We are producing goods at $20-30 \%$ capacity due to energy Short falls. Due to Electricity shortage, and Electric Generators, and stealing the electric companies keep raising prices Nuclear Plant can produce 10 times the electricity needs of our country Our Industry can run $100 \%$ capacity produce more revenue. We can run projects such as Subways, Trains on Electricity not to mention fences with electrical barbed wires. An investment of 10 billion into Solar Energy, program to put few solar panels in every home, instead of people buying electric generators could solve the energy crisis. People should sell their generators. But high capacity solar panels. You can run whole house on modern solar panel that cost $600 \$$ for $5,000 \$$ you can be energy get $75 \%$ of your house electricity. The load on Electric companies would be lifted if we spend 10 billion on programs to get 4 solar panels up in every home and the extra energy could go $100 \%$ to our Industrial Sector. But Nuclear energy is short term answer to give us relief for 50 years (Pakistan Defense, 2011).

Pakistan Power Generation Projects: China to invest in hydel, renewable energy power projects. Islamabad: China will invest in hydel and renewable energy power projects in the country as well as join hands with WAPDA for development of various large-scaled hydropower power projects. Chairman of the state owned China Three Gorges Project Corporation (CTGPC), Cao Guanging heading a ten-member Chinese delegation met with Federal Minister for Water and Power and Privatization, Syed Naveed Qamar here Tuesday. The delegation also showed interest to establish local manufacturing of wind power equipments in the country (Pakistan Times, 2011).

Recently, there have been numerous calls from various political parties for a national consensus on major issues. 
This is welcome for the need is to take a cohesive stand on the challenges the country faces. In this respect, the energy crisis is one of the biggest challenges Pakistan faces today. It demands a broader national consensus. The issue should be on the list of priorities for the subjects to be discussed at any conference with national representation. In fact, the energy crisis is too big a problem to be addressed without concrete consensus and demands a national energy agenda. While the energy crisis continues to pound the socio-economic fabric of Pakistan, both at the micro and macro level, the initiatives taken so far by the concerned authorities have not shown the ability to arrest the problem. The crisis cannot be addressed unless one of the most devastating and chronic issues - the short-sightedness of successive governments - is not addressed. It is imperative that the authorities concerned realize the importance of sustainability of an energy agenda. A usual problem in Pakistan`s official circles is the absence of vision and a sense of responsibility. The energy history of the country reveals that, barring a couple of exceptions, no government has served this sector well. The short-sightedness of governments over the last three decades has had a detrimental impact on the energy sector. They have failed to look beyond their tenure in office. Moreover, a project-oriented approach rather than a goal-oriented one is visible. The focus has been on ad hoc and quick-fix solutions. There are no trends of long-term and sustainable planning. Value-engineered and cost-effective solutions are unheard of in the corridors of power. Energy projects in general require rigorous planning and huge investment. Unfortunately, reluctance to develop sustainable energy projects has been the main reason behind the current energy crisis. This attitude has to change if the gigantic energy challenge the country is facing is to be adequately addressed (Asif, 2011).

Dilemma of Pakistan: It is said that Pakistan is presently facing the most critical problems of its time. These problems if not tackled properly could change the future of the country. At the onset these problems could be categorized into four major classes. First are the problems originating from the government itself, such as corruption, bad governance, law and order, power shortage, unemployment, price-hike, etc. The next category is that of problems originating from the people, such as, religious extremism, sectarian violence, blasphemy issue, madressa issues, terrorism, etc. Third are the economic issues, like trade deficit, excessive government expenditure, foreign and domestic loans, inflation, etc. The forth category of problems are those which are purely political in nature such as the issues emanating from lack of the absolute majority of the ruling party in the Parliament, exploitation of such issues by the party leaders, political immaturity, polarization in society, insurgency like situation in Baluchistan, war on terror, fighting extremism, etc. (Pak International Friendship Forum, 2011).

\section{Problems Facing Pakistan - Comprehensive List (based on people perception and literature review)}

All or most of these problems are common to many developing countries:

Army Rules; Afghan War; Bureaucracy in Government; Budgets base on Borrowed Funds and Bad Planning; Corrupt Leaders; Lack of Governance; Corruption in Departments; Electricity Terrorism; Electricity Load Shedding; Economic Terrorism; Foreign Policy; Feudalism; Islamization; Indo-Pak Relations; Inadequate Transport; Traffic and Safety Planning/Management Issues; Inadequate Economic Development; Illiteracy; International Interference; Leadership Gap; Lack of Health Infrastructure; Lack of Unity \& Spirit of Brotherhood; Terrorism; Population Explosion; Lack of religious and moral values; Lack of ability and spirit of Patriotism in common man; Poverty and Unemployment; Popular Provincial Disharmony; Political Instability; Unemployment and; Rising Prices of basic commodities/Sugar \& Gas.

\section{Ten Most Important Problems}

A survey ranking of the ten most serious issues facing Pakistan gives a public perception (see Model A, figure $1)$.

$$
\text { Insert Figure } 1 \text { here }
$$

\section{View Poll Results: What is the Major Issue/Problem in Pakistan (Multiple Choice Poll)}

Another survey of more problems faced by Pakistan gives another public perception of the issues (see Model B, figure 2).

$$
\text { Insert Figure } 2 \text { here }
$$

\section{Energy Crisis A Case-in-Point}

\subsection{Economic Crisis of Pakistan}

In 2011, economy of Pakistan is at its worst. Severe electricity and gas shortage are having an adverse impact on the industry of the country. To understand this impact, it is important to briefly review the economic crisis of Pakistan - its challenges and perspectives. 
Dancing around the fire is not the solution to any problem. One should try to see beneath the surface in order to grasp an idea about the basic issue. Deposit a stream of strong words and announcements made by the past rulers of Pakistan, nothing concrete has been done to introduce a proper economy revival plan. Rather the situation has taken a quantum leap for the worse. At present the sorry state of the economy, tops the problems facing the country. Therefore, the present leadership has realized that there is no option but to reshape the economic strategy altogether. The economy of Pakistan has fallen up to this extent that it requires serious attention and endeavor to revive its state. The revival of economy means to bring the economy on track whereby country becomes self sufficient and economy self sustained to meet its internal demands and fulfill foreign obligations. For the last thirteen years there has been no noticeable addition to basic industries and the economic infrastructure of the country. Instead the number of sick industrial units increases each year. The public sector is shrinking and suffering losses. External debt is touching new heights and the irony is that new loans are obtained simply to pay back a portion of the earlier loans. The real issue of our economy is how to achieve higher productively, and to strengthen and develop the infrastructure. For this purpose the foremost need is to restore the confidence of our businessmen, cultivators and industrials to engage them in product processes. The combination of malnutrition, illiteracy, diseases, high birth rate, unemployment and low income has closed the avenues of escape from serious economic crises. The most unfortunate aspect of these serious economic crises and pathetic state of affairs is not because of the lack of natural resources but due to inefficient use of the key factors of production (Free Education Worldwide, 2010).

\subsection{Energy Self-sufficiency}

Energy self-sufficiency is an important variable in a country's economic development model. Achieving self-sufficiency in electricity and gas supply to the industry and home consumers is very important for national economic development and for avoiding further political turmoil. Energy Means ability to do work. We are in the age in which science is doing what magic cannot do. Especially in energy sector, people are shifting towards green and unlimited and economical foams of energy. With the help of science, nations are focusing to do more against less to sustain their economy and also compete in the international market.

India is both a major energy producer and a consumer. India currently ranks as the world's seventh largest energy producer, accounting for about $2.49 \%$ of the world's total annual energy production (Eleventh Five Year Plan, 2010).

In case of Pakistan (the seventh nuclear power in the world) the situation is totally adverse. Pakistan claims bulk of important resources like uranium, coal, natural gas, oil, wind, solar, hydel, scientists, engineers, institutions, donor agencies, ministries, skilled workers, labor force. But, the overall result is that we are facing $4500 \mathrm{MW}$ electricity shortfall ((Annual Plan 2010-11, 2010), our electricity tariff is Rs 17/kwh and regularly rising shortage of Oil and Gas, unreliable pricing system, huge amount of T\&D losses (electricity and Gas), deforestation, health issues, infrastructure leakage, poor technology, and no practical interest toward nuclear and renewable energies (Overseas Pakistani Friends, 2008). As a result, we are facing economical crises in Pakistan due to short supply of efficient energy to our industry and agriculture (which is contributing about $90 \%$ to our GDP) thus facing a huge crises. And the economic cycle is gym in Pakistan and this shift Pakistan into other problem.

The aim of this study is to highlight all the Issues and its statistics and its dependence on each other. Which are under estimated in last decades. As we all know that now the treads are changing and regions are adopting the new techniques and also highlighting the facts. And every institution on their behalf paying the role and make the country trouble-free to achieve the goal.

In the given text it is highlighted that what the ground reality is, on the soil of Pakistan in terms of Energy. And also calculated all the statistics and opportunity costs and some surrounding examples and some facts which directly and indirectly moving us towards the ruin.

\subsection{Electricity issues in Pakistan}

The total generation of electricity in the world is $17363930 \mathrm{GWh}(2005)$. Out of this $11455120 \mathrm{GWh}$ is generated from Conventional thermal, $2897800 \mathrm{GWh}$ from Hydroelectricity, 2639250GWh from Nuclear and 371750 GWh from Geothermal, Solar, Wind and Wood and Waste (U.S. Energy Information Administration, 2011), see figure 3. In Pakistan the total electricity generation is $91626 \mathrm{GWh}$ (2008-09). In which oil contributes $35.4 \%$ (32433GWh), gas added 32.4\% (29678Gwh), Hydro 30.3\% (27784GWh), nuclear 1.8\% (1618GWh) and Coal $0.12 \%(113 \mathrm{GWh}$ ), see figure 4. The Consumption scenario 2067GWh is used by industry its own and $21.6 \%$ $(19,396 \mathrm{GWh})$ electricity is wasted in transmission and distribution (SIAST.PK, 2011). At last the bulk of 70,371 GWh [2] electricity is available for industry, transport, Residential and commercial, etc. The residential sector is 
utilized 45.9\% (32282GWh) followed by industry 27.5\% (19330GWh), Commercial and Public services caught 14.2\% (9960GWh) and Agriculture/Forestry contributes 12.5\% - 8795Gwh (Pakistan Energy Year Book , 2009), see figure 5 .

Insert Figures 3, 4, and 5 here

\subsection{Electricity Efficiency potential in Residential and Industrial Sectors}

Residential sector consumes 32282 GWh electricity (Pakistan Energy Year Book, 2009). This sector consists of more than 24 million household. Out of which 70\% have an excess of this source. The given amount of electricity is utilized by $29 \%(9362 \mathrm{GWh})$ for general appliances (water pumps, irons, television etc), 36\% $(11622 \mathrm{GWh})$ for space cooling (fans, room cooler air conditioner etc) and 35\% (11299GWh) for lighting Incandescent bulbs, Florescent tube lights and compact candescent lamps etc. (Asian Development Bank, 2009). Due to lack of awareness $30 \%(9684.6 \mathrm{GWh})$ of electricity is smashed .By the introduction of standardized appliances, we can save this huge amount of electricity (Enercon Pakistan, 2009). In industry sector 19330GWh electricity is used (Pakistan Energy Year Book, 2009). From this electricity 6.4\% (1237GWh) electricity is consumed by steel and iron, 3\% (580GWh) by pulp and paper, 27.6\% (5335GWh) textile, $0.8 \%(155 \mathrm{GWh}) \mathrm{sugar}$ and 62.2\% (12023GWh) for other industries (Asian Development Bank, 2009). Electricity efficiency potential in industrial sector is 25\% (Enercon Pakistan, 2009).

\subsection{Electricity Efficiency potential in Commercial and Public services}

The commercial and public services consist of offices, shops, Markets, hotels, government organizations, street lights etc utilized $9960 \mathrm{GWh}$ electricity. Out of this $5252 \mathrm{GWh}$ consumes in purely commercial sector and remaining 4708GWh for public services (Pakistan Energy Year Book, 2009). In commercial sector the pattern for electricity is $26 \%$ for general appliances, $36 \%$ for space cooling and $38 \%$ for lighting. And in public services 4176GWh is used for Bulk supply, 430GWh for street lighting and 103GWh for other government utilities (Pakistan Energy Year Book, 2009). By the enforcement of standardization, we can safe 30\% of electricity also in these sectors (i.e. by replacing incandescent bulbs with compact fluorescent bulbs, upgrading fluorescent tube lights etc.) (Pakistan Energy Year Book, 2009).

\subsection{Electricity Efficiency Potential in Agriculture/Forestry}

The electricity in this sector is only used for water pumps. According to Pakistan machinery census 70981 Tube-wells are operating till 2008 (Asian Development Bank, 2009). As we all know most of the pumps are made locally or import from china. These pumps are highly inefficient so a huge amount of electricity is wasted. But by the implementation of proper consultancy $20 \%$ of electricity can be saved during the operation Enercon Pakistan, 2009).

\subsection{Petroleum Product Issues of Pakistan}

Pakistan is not self sufficient is this sector .Pakistan produced 3554 ktoe crude oil and imports 8511 Ktoe and as a result Pakistani refineries (Attock refinery, Bosicor refinery, Pakistan refinery, National refinery, Pak-Arab refinery etc) processed this available crude oil into petroleum products (Motor spirit, Kerosene, HOBC, LDO, FO, HSD, Naphtha and LPG etc ). The total available petroleum products were 20740 ktoe (production + Import). Out of this 7401 Ktoe was consumed by Electricity power plants, 8873Ktoe [2] was used for transport sector, 971 Ktoe for industry, 453 Ktoe for residential, 387Ktoe devoted for commercial and public services and 74Ktoe in agriculture/forestry etc. (Pakistan Energy Year Book, 2009).

\subsection{Petroleum Product Efficiency potential in Power plants}

The power plant consumed 7401 Ktoe Petroleum Products consist of 7210.211 Ktoe Furnace Oil (FO) and 173.947 Ktoe High Sulfur Diesel (HSD) and produced 31748.6 GWh electricity from FO and 673.9 GWh electricity from HSD (Pakistan Energy Year Book, 2009). 294118927MMBtu of Furnace oil (7210.211 Ktoe) produces 101290443 MMBtu Electricity (31748 GWh) and 7287639 MMBtu (173.95 Ktoe) HSD produces 2300000 MMBtu $(673.9 \mathrm{GWh})$ electricity. These statistics shows that $37 \%$ MMbtus are consumed in FO and $32 \%$ for HSD. So a huge saving potential is obtainable in this sector (U.S. Energy Information Administration, 2011).

\subsection{Petroleum products Efficiency Potential in Industry and Transport}

Only 971Ktoe energy is used in industry sector(Pakistan Energy Year Book , 2009) Which was further disintegrated into $3.7 \%$ into steel and iron industry, $4.6 \%$ to pulp and paper, $5.1 \%$ to textile, $6.2 \%$ added by sugar, $13.8 \%$ used by cement and $66.5 \%$ used by other industry(Asian Development Bank, 2009). On the basis of this data we can conclude that $20 \%$ of $971 \mathrm{ktoe}$ can be saved through technical and introduction of applied 
management and replacement of poor condition machines (Enercon Pakistan, 2009). Transport sector is the backbone for any civilization. Its influence plays a tremendous role $10 \%$ GDP and $17 \%$ to the GCF (ADB, 2010). It is basically operating system for any sector. In case of Pakistan 8873 Ktoe (SIAST.PK, 2011) petroleum products was consumed in transport. Out of this $83.5 \%$ were HSD and $16.5 \%$ Gasoline (U.S. Energy Information Administration, 2005). By applying little attention on vehicles (i.e. tuning on time).we can safe $20 \%$ (1775 Ktoe) and overcome a huge burden of import bills (Pakistan Energy Year Book, 2009). Conversion table used from Energy year book.

\subsection{Natural Gas Issues of Pakistan}

Natural Gas is back-bone for energy sector. The total production of gas was 1433 Billion Cubic feet (2008-09). There are two main companies SNGPL and SSGC. Who have taken the responsibility of transmission and Distribution of Natural Gas. There is huge number of losses in this sector. The estimated losses of SNGPL and SSGC for year 2008-09 were 191 Billion cubic feet. The remaining 1269 Billion Cubic Feet Natural gas was distributed by a ratio of $31.8 \%$ [2] to power sector, followed by $41.6 \%$ to Industry, $7 \%$ to transport (CNG), $16.9 \%$ to residential and 2.8\% to commercial sector (Pakistan Energy Year Book , 2009), see figure 6.

\section{Insert Figure 6 here}

\subsection{Natural Gas Efficiency Potential in Power Sector}

The Power Sector Consumed 403.5 billion Cubic Feet (31.8\%) natural gas and provided 29678 GWh Electricity (Pakistan Energy Year Book, 2009). In terms of efficiency 326252708 MMBtu (403.5 billion Cubic Feet) (1) gas produced $101290443 \mathrm{MMBtu}(29678 \mathrm{GWh})(1)$ electricity. It shows that $31 \%$ was fruitful and the remaining $69 \%$ was flash out (U.S. Energy Information Administration, 2011). More than 70\% Gencos power plants are 15 year old and operating on a very low efficiency. The Kotri Gt power plant thermal efficiency is $20 \%$, Quetta Tps power plant efficiency is $21 \%$, Faisalabad Gt power plant efficiency is $21 \%$, Multan Steam has $22 \%$ and Shahdara GTPS is only $12 \%$ etc. (Asian Development Bank, 2009).

\subsection{Natural Gas Efficiency Potential in Residential and Commercial Sector}

The residential and commercial sector used 79.5 billion cubic feet natural gas (Pakistan Energy Year Book, 2009). The natural gas consumption pattern in residential sector is $63 \%$ for cooking, $21 \%$ for water heating and $16 \%$ for space heating and in commercial sector $92 \%$ natural gas is used for Cooking, $6 \%$ for water heating and the remaining 2\% was used for space heating (Asian Development Bank, 2009). The energy efficiency potential in residential and commercial sector is 30\% (Enercon Pakistan, 2009).

\subsection{Natural Gas Efficiency potential in Industry and Transport}

The total natural gas utilization in industry sector was 528 billion cubic feet (41.6\%) (SIAST. PK, 2011). In this $9.3 \%$ used by steel and iron, $12.9 \%$ pulp and paper, $27.7 \%$ textile, $2.6 \%$ for sugar, $9.1 \%$ for fertilizer (fuel), $3.5 \%$ for cement and the remaining 35\% for other industry (Asian Development Bank, 2009). This sector consuming huge percentage of natural gas and by the implementation of sharp techniques $25 \%$ of natural gas can be saved (Enercon Pakistan, 2009). Pakistan is paying only 7\% of natural gas to transport sector in the foam of CNG (Pakistan Energy Year Book, 2009). There are more than 1700(2008) CNG stations. The $20 \%$ of CNG can be deducted by implementation of energy efficiency manuscript (Asian Development Bank, 2009).

\subsection{Coal and Peat Issues in Pakistan}

The total available coal was 4748 Ktoe (2008) From this only 1679 Ktoe was indigenous product and the left over 3069 Ktoe was imported. The 50.341 Ktoe was consumed for electricity power plants for electricity production. And the remaining $4187 \mathrm{Ktoe}$ was consumed in industry. In industry only two sectors are the big customer of it (Pakistan Energy Year Book, 2009). The 68.9\% was used by cement and $31.1 \%$ by brick kiln (Asian Development Bank, 2009).

\subsection{Coal and Peat Efficiency Potential in Power Plant and Industry}

The total coal used by power plants are 2108606 MMBtu (59.341Ktoe) (1) and as a result they generated only 386348MMBtu (113GWh) (U.S. Energy Information Administration, 2011). It shows that this sector is $19 \%$ efficient. In presence scenario Lakhra Fbc power plant (Genco IV) is $22 \%$ efficient (Asian Development Bank, 2009). The 4187 Toe [(Asian Development Bank, 2009) Coal and peat was used by industry in 2008-09. The saving potential in this sector is $20 \%$ (Emerson Pakistan, 2009).

\subsection{Renewable Energy and Nuclear Energy Issues}

Pakistan has enjoying its 62 years of independence but unfortunately till to now we are facing energy shortage 
problems. In parallel air pollution, water pollution. We need to put in order only those policies through which we fulfill our demand as well as green energy. And their many examples existing around us i.e. South Korea has installed $18000 \mathrm{MW}$ from Nuclear and $350 \mathrm{MW}$ from solar and India is also in front list by adding $4120 \mathrm{MW}$ nuclear and 11806 MW wind Energy power plants. The Pakistan has added only 462 MW nuclear energy in the system. And in solar energy only finger counted houses are benefited from this technology with the help of A.E.D.B and PECRIT. And same here in wind power. So a very serious eye is required in this sector.

\subsection{Infrastructure Issues in Pakistan}

As per statistics of Pakistan, total house units in Pakistan are 22.38 Million (2005-06). In this Punjab contributes $54.85 \%$ (12.28 Million), followed by Sindh 26.14 \% (5.022 Million), Khyber Pakhtoon Khuwa 11.5\% (2.57 Million), Baluchistan 5.05\% (0.0971 million), FATA 1.77\% (0.34 million) and Islamabad 0.129 Million. Only $20 \%$ are enjoying Natural gas facility and remaining $80 \%$ are using other non conventional resources (Fuel Wood, Dry Dung, Crop Residue, Kerosene, Charcoal and LPG etc). Lack of infrastructure is the basic cause of deforestation, using low Btu value fuels, health hazard fuels etc. The revenue required for $100 \%$ gas infrastructure is 1.09 trillion rupees (see Table 1).

\section{Insert Table 1 here}

\subsection{Non conventional Energy Issues}

In Pakistan the total 28 Mtoe (2008) energy was used from Non Conventional Energy Resources (Fuel Wood, Charcoal, Cow Dung, Crop Residue, Industrial Waste, Municipal Waste Etc). In this statistics fuel wood contribute 26,500,000 $\mathrm{m}^{\wedge} 3$, Charcoal 64,000 ton (2005) and Biogases 9,000,000 ton (2005), etc. (EnergyPakistan, 2011). By using these Energy resources, Pakistan is facing many challenges /Problems directly or indirectly. First highlighted issues caused by make use of these resources are deforestation. (forest statistics and its annually plantation vs. success rate). This massive rate of Deforestation cause the Soil Erosion, Green House Gases, Air pollution, Temperature rise Etc. Health Issues are also mounting by regular use of charcoal, cow dung, Air pollution, water pollution etc. (Health issues statistics). Environmental issues are also upcoming very rapidly. El Nina is the basics tumor of our surrounding. The Pakistan is getting 50\% GDP from agriculture but these issues suffering a lot to our Economy as well. Food Security is also forecasted to be a problem. If our population increases on the current rate and our agriculture ratio declines it is very difficult to defend the gap. As we all know, Pakistan has $70 \%$ population in rural areas where the energy source is these Non Conventional Energy. So to get this energy they spend a lot of time which caused that they lost opportunity cost and indirectly its effect is seen by studying Pakistan exports/imports and lack of cultural development, lack of small industry, Lack of education etc. And more important issue is that it contains very low Btu value and its efficiency is very Low. Economic worth of this energy is 612 Billion Rupees/Year. It means by supplying Conventional energy resources; we can save such a huge amount which we are paying for the sponsorship of these issues.

\section{Solutions for Energy Crisis}

6.1 Solutions for Pakistan's Issues Related to Energy

Data:

$\begin{array}{ll}\text { Inflation } & 11.17 \% \\ \text { Per Capita income } & \text { US \$ 1095 (2009-10) } \\ & 4.1 \%(2009-10) \\ \text { GDP Growth Rate } & 21593 \mathrm{MW} \\ \text { Installed Generation Capacity } & 21063 \mathrm{MW} \\ \text { Peak Power Demand } & 21.63 \mathrm{million} \\ \text { No of Electricity Consumer } & \text { approx. } \\ \text { Per Capita Electricity Consumption in Pakistan } & 470 \mathrm{kWh} / \text { annum }\end{array}$

Source: PPIB Pakistan

\subsection{Energy Management}

As we all know that Pakistan is facing huge energy crises in terms of Power shortage, Oil and Gas shortage, Price mounting. All these issues are directly and indirectly affecting the peoples of Pakistan. To overcome from these issues, we can apply some tools of management and make it possible to finish all the existing problems. From the given statistics, we come to know that 429.8GWh (2008-09) electricity was consumed for street lights. Ninety Percent street lights are consisting of 100 watt/500 Watt fluorescent bulbs. These lights must be replaced by Compact Fluorescent Lamps. We can save $80 \%$ of $429.8 \mathrm{GWh}(343.84 \mathrm{GWh})$ per Annam. In household 
Sector 5641GWh (FY2008) was used for lighting. Out of which 37\% (2087.2GWh) energy was used by Incandescent bulbs. It means that we can save $80 \%$ of $2087.2 \mathrm{GWh}(1669.76 \mathrm{GWh})$ per annum by simple replacing it with Compact Fluorescent Lights. So if our government bans the incandescent bulbs in Pakistan then we can save 2013.6GWh Per annum. In commercial sector, 1537GWh (FY 2008) was used. Out of it $25 \%$ $(384.3 \mathrm{GWh})$ was used by incandescent bulb. And from these bulbs we can save $80 \%$ (307.4GWh) of electricity by simply replacing it with compact fluorescent bulb (Asian Development Bank, 2009). Refrigerators used 4524GWh (FY 2008). Out of it 24\% (1085.8 GWh) are used by inefficient refrigerators. In which $67 \%$ $(727.45 \mathrm{GWh})$ can be saved by applying improvements. For water pumping, domestic sector used $1258 \mathrm{GWh}$ (FY2008). The 90\% un-standardized pumps were used and we can save 50\% (566 GWh) electricity by improving its quality. Air conditions were used 5845GWh (FY2008). Proportion of inefficient appliances was $29 \%$. And improved potential is $40 \%$. So we save $678 \mathrm{GWh}$ by handling it technically (Asian Development Bank, 2009).

\subsection{Sustainable Policies}

Law-and-Order is the basic ingredient for the promotion/development of any country. There are two types of steps, which our government has to take to overcome the issues. For a sustainable Exploration and development. And to catch foreign investment in Energy Sector, we need a strong Judiciary and Law and Order Position in Pakistan. Without it, we cannot be able to explore and develop the indigenous resources (Oil, Gas and Coal). In 2005-06, we produced 65,578 Barrels Crude Oil per day (SIAST.PK, 2011) and now (2008-09) we produced 65,844 Barrels per day. As a result we have imported 8.061 Million Tons of Crude Oil (2008-09). And we have paid 4243.71 Million US \$. The refining capacity of Pakistan refineries are 12.95 Million tons per year in 2009.

In terms of Natural Gas, we have blessed with 150 Trillion Cubic Feet (TCF) Prognosticated Reserves as of 2009 (Asian Development Bank,). In contract we produced 1400 Billion Cubic feet in 2005-06 and only 1460 billion cubic feet in 2008-09. And after the study of statistics, we come to know that we only increased $0.45 \%$ from last year (2007-08). In comparison we know that in 2003-04, we achieved $21 \%$ increased from previous year (Pakistan Energy Year Book, 2009). So we have a lot of potential in terms of Reservoirs and Technocrats.

The second thing is that we must implement international rules in our Up-stream, Mid-stream and Down-stream level. In Pakistan there are many power plants which are running with 12-30\% efficiency (Asian Development Bank, 2009). Pakistan is also facing huge energy losses in Transmission and Distribution. In power sector, it is almost $21 \%$ and in Natural Gas sector its almost 13\%. In downstream level, we are using 100 watt bulbs in the age of 2-3 watt bulbs (Pakistan Energy Year Book, 2009). We are also using inefficient lights, fans, water pumps, air conditions etc. If our government applies tangible rules and regulations in Mid-stream and Down-stream level then we can never import any type of energy and also overtake the energy shortage.

\subsection{Real Statistics/Forecasting}

It the most important pillar to design any policy/plan or any other research/decision.

But unfortunately in Pakistan, we are neglecting its importance and deal in as very unimportant way; as a result our any plan or policy on the bases of that data is not sustainable. Now the census (2011) is going and government spent 70 billion rupees (Federal Board of Statistic, 2011) but they are not carrying it as a world standard. In develop countries, Government apply curfew and take the real figures/data. In short, to take any step you always need authentic data. So our Government should take a serious eye towards this department.

\subsection{All the Issues are included in Academia}

Schools, Colleges, Universities and research departments are the real stake holders in the process of grooming. So it is very important to review our academic courses yearly and also put country issues/solutions in it. So to-overcome the given issues, its basic need to include the case-studies into our courses and highlight it. And also scratch the solutions from the fresh and experimental minds. And made it possible by implementing it into our young scientists and Engineers. Their research and study directly benefit the society/industry. As we all know that we have 128 Universities (Answers.com, 2011). More than 1,349,000 post secondary Students in our institution (Education_in_Pakistan, 2011). So it will be beneficial for both students and local industry to make a proper road map. As like a develop countries, it is very obligatory for wealthy indigenous industries to strong their institutions. Solid Research in universities and it is liked with industries makes it very tangible. For-example LG and Samsung are the top class companies of South Korea. And now enjoying the world class profitable organizations status. Just because of its deep co-operation with South-Korea Universities (i.e. Soul, Kiest etc). 


\subsection{Make Media (Electronic and Printtatistics). as a Base Line}

Strong and Independent media is the back bone for any nation. In Pakistan they are totally independent and can play a vital role to direct the nation towards the row of develop nation. And also highlight all the negative/poor decisions from the government. They are also acting like a ministry in which they set check and balance on any institution/department. So it is right time to focus all the other issues (Economy, Energy, law-order, foreign investment, deforestation and Health etc). They can also be the ambassadors of our nation and they can focus the attention of investors (Local/foreign). And more important through this medium we can aware all the existing and foresee problems to nation of Pakistan.

\subsection{Efficient Devices (Electronic and Mechanical) Availability}

As we all know that Pakistan is facing huge energy efficiency, Conservation, Pollution, Un-standardization Problems. On another hand, we have Ministry of Environment, ENERCON, PSQCA (Pakistan Standard and Quality Control Authority), PCSIR (Pakistan Council of Scientific and Industry Research). We have all the required institutes but till to now we are unable to show the physical results. Just because of political and Economic Constraints. So to strengthen the above institutes, Government should cooperate and allow them to take bold steps and through ordinance their implantations can be possible. And it can be possible to improve the standardization as well as improvement in the existing structure.

\subsection{Make a Transparent and Sustainable Policy}

Transparency is the basic for success and foundation for merit. All the policies, Plans, Tenders and other key decisions should be transparent and approachable to general Public. We are enjoying sixty three year of independence and in that period we made many policies and plans to move our country in the world ten list countries. Because we are nation having lot of resources, For-example Coal, Gas, Uranium, Sun, Wind, Sea, Waterfalls etc. We have best Universities, Research institutes, skilled Workers and best technocrats and also we made ten plans (5 year plan), we have vision 2030. We have all the data of required questions. But as a result we are facing huge crises in all stages of life. It means that we have some problem in our documentation. There are some technical flaws in our Proposed Plans/Policies. In every Policy/Plan we only consider the general summary but we never assign the duties to the required Person/Department. No Terms of Reference are made. We never describe it micro level. We never differentiate it with respect of time. It is never defended by law and order agencies. No securities are assured to local and Foreign Companies. Neither check nor balance system is introduced against it. That's why all the plans and Policies are neither fruitful nor produced tangible results. Switch off-from Non-Conventional Energy Resources (Fuel Wood, Dry Dung, Crop Residue). Pakistan is consuming 8 MTOE Conventional Energy and 22 Mtoe Non-Conventional Energy in Domestic sector (Pakistan Energy Year Book, 2009). It means that people are spending most of their time to collect energy resources (Fuel wood, Dry Dung and Crop-Residue).And these resources consist of Low Btu value and Health hazards. As a result deforestation and environmental issues are generated. To conquer the describe issues we should provide infrastructure to carry conventional energy door to door.

\subsection{Economic Solutions}

\subsubsection{Generation of Revenue for sustainable Projects}

In Pakistan, we have facing two big constraints: Political and Economic Constraints. All the projects were jammed just because of these constraints i.e. Kala Bagh dam etc. In Pakistan there are many Local $(\ldots \ldots \ldots \ldots \ldots \ldots . .$.$) and Foreign (Asian Development Bank, World Bank, United Nation (U.N.D.P), CIDA,$ Islamic Bank) Organizations Which are ready to execute the Energy Projects having sustainable Environmental and Economic Concerns.

\subsubsection{Solutions for Circular Debt Issues}

According to the former chairman WAPDA, engineer Shams-ul-Mulk, there is no electricity shortage present in the country and the present electricity crises is the result of nonpayment (of circular debt) to the IPPs. Pakistan is Facing 700 billion rupees circular debt in Energy sector. For example 284 billion rupees are given to hydel, IPPs, Nuclear and Gencos by PEPCO. Like it IPPs are given 166 billion rupees to PSO. Our provinces have given 134 billion rupees to PEPCO. So 300 billion rupees are required.

\subsubsection{Solutions taken by our government required to die out this Circular Debt issue}

Revamping PEPCO's collection system through implementation of efficient ERP. Accounting systems and through the hiring of professionals; Controlling Distribution and transmission losses; Construction of more dams in order to conserve the rapidly depleting water resources; Energy sector needs to experiment with alternate, 
renewable energy sources for production of electricity; like wind, hydel, solar etc.; Use Coal reserves found in abundance in Pakistan as a fuel source; The National Natural gas companies should make it a priority to produce an additional 300-400 million cubic feet of gas which is quite possible if gas tariffs are raised to economic levels; The power infrastructure should be upgraded with a modern efficient grid; Timely recovery of receivables of state owned Power distribution company PEPCO from Provincial/ Federal governments and departments; The existing net balance position should be specifically determined and cleared through issue of debt instruments by the Government. Further, to prevent future increase in the circular debt, the hemorrhaging between the sale price (tariff) and the cost to the Distribution companies should be eliminated; Prices of all energy products should be rationalized through cross-subsidization; Price subsidies should be eliminated and fuel prices be linked to prices quoted internationally; Targeted subsidies should be offered only if required for social reasons. and paid for out of government revenues not by energy producers; Petroleum Levy collected by GoP on POL products should be utilized to support the power sector for settlement of their debts; Tax-free Energy Bonds can be issued to the general public to raise funds for periodic resolutions of circular debt; Netting off of receivables and payables of the involved parties and; Increase in the direct tax collection.

\section{Conclusion}

Five main root causes of Pakistan's energy crisis are lack of integrated planning, imbalanced energy mix, non-utilization of vast indigenous resources, lack of effective project structuring and inadequate primary energy sources (Ahmad, 2009). One aspect of solutions for energy crisis of Pakistan can be (Haq, 2008): (1) Load shedding in Pakistan is acute and Government Policies but Government has not taken sufficient steps to solve this problem; (2) Iran offered to supply the electricity urgently on very cheap rates of about one third of Regulated Price Plan (RPP); China offered to supply the electricity at the cost of Rs. 300/month for unlimited usage; Pakistan is in severe energy crisis but America is not doing any sort of help to solve this problem. However it is enforcing to the government of Pakistan to impose new taxes on electricity and fuel prices. Government of Pakistan should act in the interest of people of Pakistan to reduce their sufferings by providing uninterrupted electricity at reasonable rates. Discussion in this paper indicates the parameters that are constraint for the development of energy sector. There is the need for estimating the exact revenue required to fulfill the leakages and developments to overcome all the defined issues. Besides, this also it emphasizes on the savings, which can be generated by solid amplification of the given suggestions. This paper helps us to know the Pakistan's main energy issues resulting from nation's core problems and side effects, difficulties and constraints, and current scenario. This paper highlights all the energy issues and its connection with other sectors. It is the gate way to set the new development plan in terms of energy and make this important pillar (Energy sector) of national development more efficient and set it as an example for the other underdeveloped nations.

\section{References}

Ahmad, Munawar B. (2009). Moving towards Energy Sufficiency, Sustainability, and Sovereignty, EMR-Consult. [Online] Available: www.energyupdate.com.pk/../Munawar_B._Ahmed_EMR-Consult,_A_Ne...

Annual Plan 2010-11. (2010). Planning commission of Pakistan. [Online] Available: http://www.planningcommission.gov.pk/annual\%20plans/2010-11/Energy\%20Security.pdf

Answers.com. (2011). what is the total number of universities in Pakistan? [Online] Available: http://wiki.answers.com/Q/What_is_the_total_number_of_universities_in_Pakistan

Articlesbase. (10-27-2008). Pakistan's Energy Crisis and Its Possible Solutions. [Online] Available: http://www.articlesbase.com/self-publishing-articles/pakistans-energy-crisis-and-its-possible-solutions-617705.h tml

Asian Development Bank. (2009). Available at Technical Assistance final Consultant's report August, 2009, Pakistan: Sustainable Energy Efficiency Development Program, Financed by the Asian Development Bank (ADB), [Online] http://www.adb.org/documents/reports/consultant/pak/42051/42051-PAK-TACR.pdf

Available:

Asian Development Bank. (2010). [Online] Available: www.adb.org/statistic/pakistaneconomicsstatistics.pdf. http://www.adb.org/Documents/Fact_Sheets/PAK.pdf

Asif, M. (2011). National policy for energy. [Online] Available: http://worldarticles103.blogspot.com/2011/03/national-policy-for-energy-by-m-asif.html

Atif, Laiq A. (2011). Energy Crisis Leaves Pakistan Textiles in Tatters. The Muslim Times, [(07-07-2011). [Online] Available: http://www.dawn.com/2011/07/03/energy-crisis-leaves-pakistan-textiles-in-tatters.html 
Comstock, Owen and Boedecker, Erin. (2010). Energy and Emissions in the Building Sector: A Comparison of Three Policies and Their Combinations. The Quarterly Journal of the IAEE's Energy Economics Education Foundation, Volume 32, Special Issue. http://dx.doi.org/10.5547/ISSN0195-6574-EJ-Vol33-SI1-3.

CSS Forum (Civil Service of Pakistan). (2009). [Online] Available: http://www.cssforum.com.pk/general/discussion/26086-major-problems-pakistan.html

Daily Times. (03-10-2011). [Online] Available: http://www.dailytimes.com.pk/

Education_in_Pakistan. (2011). [Online] Available: http://en.wikipedia.org/wiki/Education_in_Pakistan

Ehtisham Ahmad. (2011). Crisis in Pakistan? Economic Policy Making in a Dangerous Neighborhood, LSA Asia Research Centre, University of Bonn, May 2011

Eleventh Five Year Plan. (2010). Energy Wing, Planning Commission of India. [Online] Available: http://planningcommission.nic.in/plans/planrel/fiveyr/11th/11_v3/11v3_ch10.pdf

Enercon Pakistan. (2009). Energy Conservation Potential in Pakistan. [Online] Available: http://www.enercon.gov.pk/

Energy Cross Roads in Pakistan. (2010). [Online] Available: http://insaf.pk/Media/InsafBlog/tabid/168/articleType/ArticleView/articleId/3932/Energy-Cross-Roads-in-Pakist an-by-Munawar-B-Ahmed-PTI-spokesperson-on-Energy.aspx

Energy- Pakistan. (2011). Nation Master Statistics. [Online] Available: http://www.nationmaster.com/red/country/pk-pakistan/ene-energy\&all=1

Federal Board of Statistic. [Online] Available: http://www.census.gov.pk/mubashir.rehman17@gmail.com

Free Education Worldwide. (2010). [Online] Available: http://www.entrytest.com/essays/essay1.aspx

Giraudet, Louis-GaÃ«tan, et al. (2010). Comparing and Combining Energy Saving Policies: Will Proposed Residential Sector Policies Meet French Official Targets? The Quarterly Journal of the IAEE's Energy Economics Education Foundation, Volume 32, Special Issue. http://dx.doi.org/10.5547/ISSN0195-6574-EJ-Vol33-SI1-12

Gravin, Jr., \& Clifton C. (1983). The Energy Crisis: Full Circle? MCB UP Ltd. Journal of Business Strategy, Vol. 4 Iss: 2, pp.60 - 62. http://dx.doi.org/10.1108/eb039021 (Permanent URL).

Haq, Nur Ul. (2008). Energy Crisis in Pakistan. [Online] Available: http://ipripak.org/factfiles/ff99.pdf

Hoicka, Christina E., and Parker, Paul. (2011). Residential energy efficiency programs, retrofit choices and greenhouse gas emissions savings: a decade of energy efficiency improvements in Waterloo Region, Canada. International Journel of Energy Research. Article first published online: 26 MAY 2011. John Wiley \& Sons, Ltd. http://dx.doi.org/10.1002/er.1860

Kou, Bing'en. (2009). Study on Energy Saving and Emissions Reduction of Thermal Plants in China. International Journal of Business and Management, Vol 4, No 10. http://dx.doi.org/10.5539/ijbm.v4n10P115

Li, Lan. (2010). An Empirical Analysis of Relationship between Export and Energy Consumption in Shandong Province. International Journal of Business Management, $\mathrm{Vol} 5$, No 3 (2010). http://dx.doi.org/10.5539/ijbm.v5n3P214

Macaluso, Nick and White, Robin. (2010). Impact of Relative Fuel Prices on CO2 Emission Policies. The Quarterly Journal of the IAEE's Energy Economics Education Foundation, Volume 32, Special Issue. http://dx.doi.org/10.5547/ISSN0195-6574-EJ-Vol33-SI1-6

Mundaca, Luis, et al. (2010). Evaluating Energy Efficiency Policies with Energy-Economy Models, Institute for Industrial Environmental Economics, Lund University, 22100 Lund, Sweden; Vol. 35: 305-344 (Volume publication date November 2010). http://dx.doi.org/10.1146/annurev-environ-052810-164840

Overseas Pakistani Friends. (2008). Pakistan Electricity crisis - a real perspective. [Online] Available: http://www.opfblog.com/2583/pakistan-electricity-crisis-a-real-perspective/

Pak International Friendship Forum. (2011). [Online] Available: http://drshabirchoudhry.blogspot.com/2011/01/dilemma-of-pakistan.html

Pakistan Defense. (05-27-2011). [Online] Available: www.defence.pk

Pakistan Energy Year Book. (2009). H.D.I.P. [Online] Available: http://libraryportal.lums.edu.pk/cgi-bin/gw/chameleon?sessionid=2009070514445708302\&skin=default\&lng=en 
\&inst=consortium\&host=library1.lums.edu.pk\%2B1112\%2BDEFAULT\&patronhost=library1.lums.edu.pk\%201 $112 \% 20$ DEFAULT\&search=SCAN\&function=INITREQ\&sourcescreen=INITREQ\&pos=1\&rootsearch=3\&ele mentcount $=1 \& u 1=4 \& \mathrm{t} 1=$ Pakistan $\% 20$ energy $\% 20$ yearbook $\% 202009 \% 20 \% 2 \mathrm{~F} \&$ beginsrch $=1$

Pakistan Times. (09-19- 2011). [Online] Available: http://pakistantimes.net/pt/detail.php?newsId=20480

Pakistan Tribune. (2010). Problems of Pakistan and Their Solution.

Sovacoo 11, Benjamin K., and Brown, Marilyn A. (2010). Competing Dimensions of Energy Security: An International Perspective. The Quarterly Journal of the IAEE's Energy Economics Education Foundation, Volume 32, Special Issue. http://dx.doi.org/10.1146/annurev-environ-042509-143035

SIAST.PK. (2011). View Polls: What are Pakistan's Three Biggest Problems Problems Today? [Online] Available:

http:/www.siasat.pk/forum/showthread.php?47263-Poll-What-are-Pakistan-s-Three-Biggest-Problems-Today.

Takahashi, Masahito and Asano, Hiroshi. (2010). An Assessment Study of Energy Efficiency Policy Measures for Japanese Commercial Sector. The Quarterly Journal of the IAEE's Energy Economics Education Foundation, Volume 32, Special Issue. http://dx.doi.org/10.5547/ISSN0195-6574-EJ-Vol33-SI1-13

Technology in Pakistan. (2010). Solutions for Energy Crisis of Pakistan. [Online] Available: http://pak-tech.blogspot.com/2010/05/solutions-for-energy-crisis-of-pakistan.html (May 30, 2010)

U.S. Energy Information Administration. (2011). World Net Electricity Generation by type (2005) [Online] Available: http://www.eia.doe.gov/iea/elec.html

Wu, Junfang and Guan, Lei. (2009). Design of the Electric Power Market Operating Model for Excess Electric Energy Consumption in Inner Mongolia. International Journal of Business Management, Vol 4 , No 7. http://dx.doi.org/10.5539/ijbm.v4n7P89

Yuan, Mei, et al. (2010). Policy Effectiveness in Energy Conservation and Emission Reduction. The Quarterly Journal of the IAEE's Energy Economics Education Foundation, Volume 32, Special Issue. http://dx.doi.org/10.5547/ISSN0195-6574-EJ-Vol33-SI1-9

Table 1. Revenue Requirement

\begin{tabular}{|c|c|c|c|}
\hline$\underline{\text { S. No }}$ & $\underline{\text { Province }}$ & $\underline{\text { Household without Gas }}$ & $\underline{\text { Cost (Rs)/Connection }}$ \\
\hline 1 & N.W.F.P & $2,160,787$ & 108,000 \\
\hline 21.090 & Punjab & 9289805 & 54,000 \\
\hline 3 & Sindh & 3085686 & 54,000 \\
\hline 4 & Baluchistan & 779721 & 240,000 \\
\hline Total Cost(trillion RS) & & & \\
\hline
\end{tabular}

Source: O.G.R.A Pakistan 


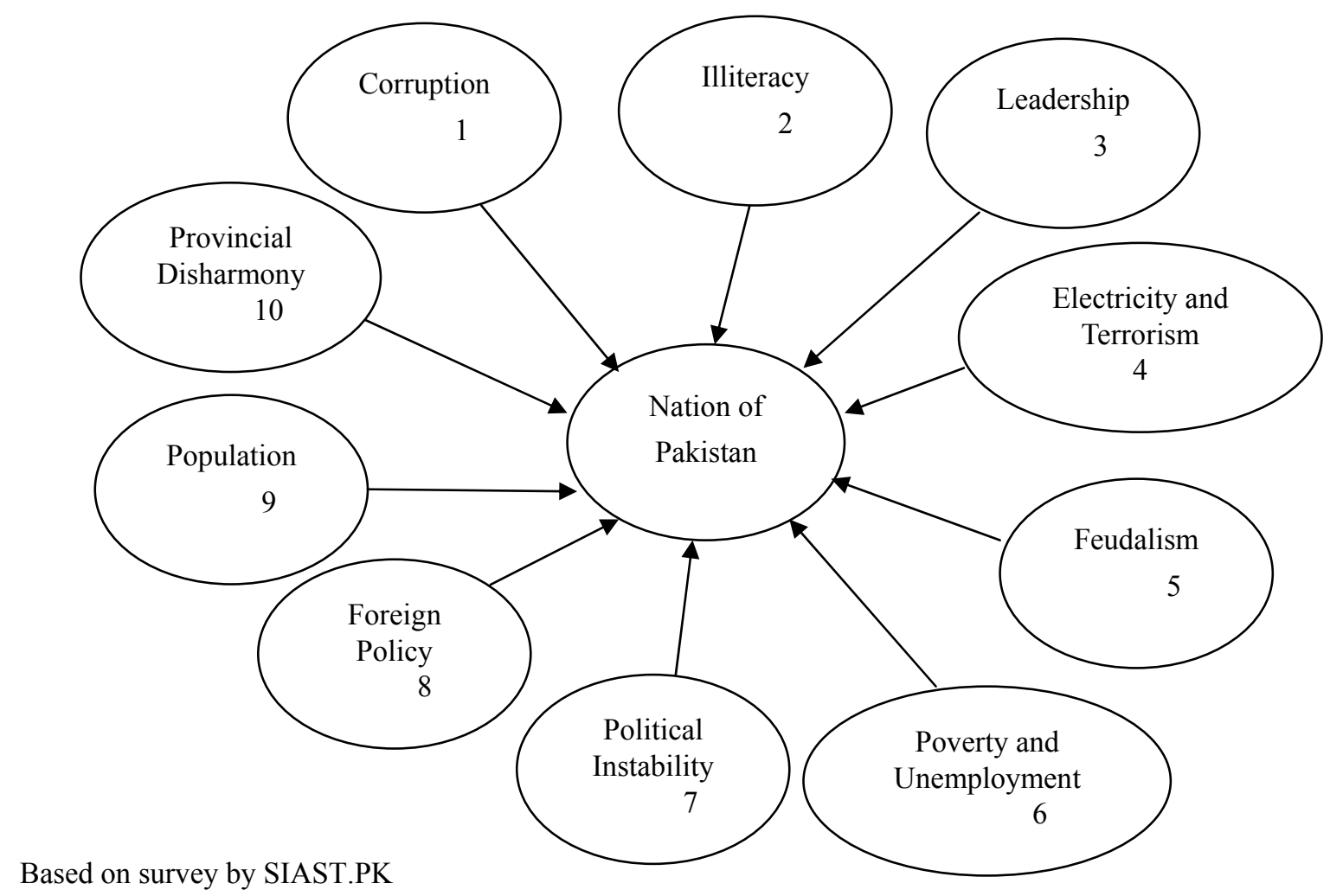

Figure 1. Major Problems of Pakistan Model A - Survey Ranking of Ten Selective Problems

Rising Prices of basic commodities/Sugar \& Gas (55.56\%)

Electricity/Load Shedding (44.44\%)

Corrupt Leaders (66.67\%)

Lack of religious values. $(66.67 \%)$

Illiteracy $(77.78 \%)$

Lack of Unity \& Spirit of Brotherhood (66.67\%)

Terrorism $(55.56 \%)$

Unemployment (55.56\%)

International Interference $(55.56 \%)$

Lack of ability \& spirit of Patriotism in Common man (55.56\%)
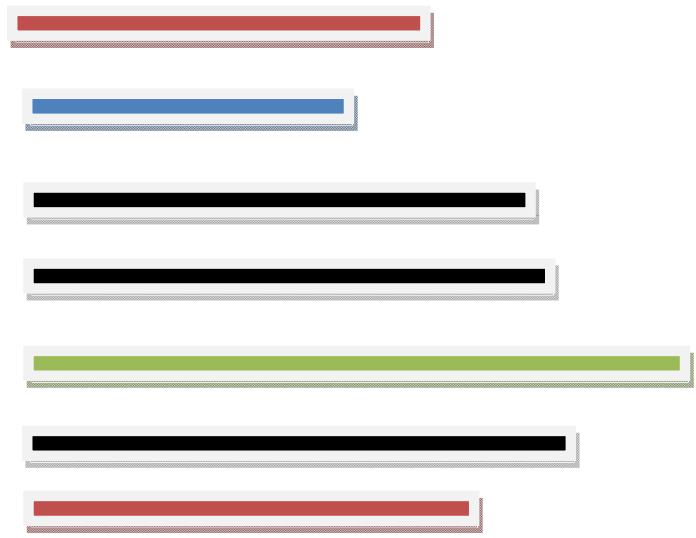

Figure 2. Major Problems of Pakistan Model B (Survey Ranking of Ten Selective Problems)

Source: SIAST.PK 


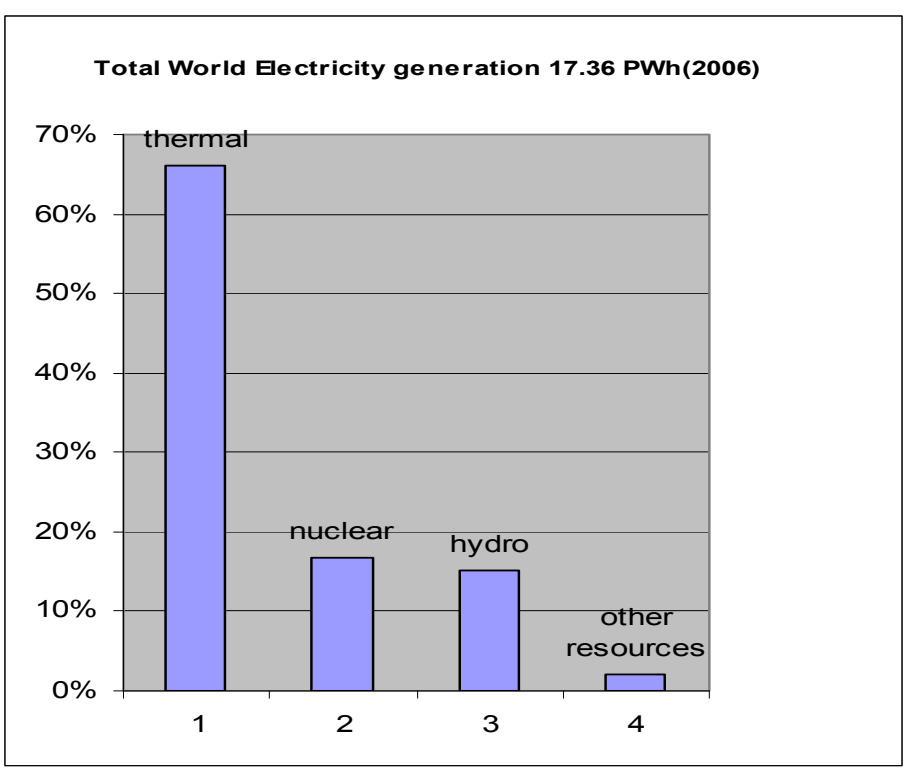

Figure 3. Total World Electricity Generation

Data source: U.S. Energy Information Administration, 2011

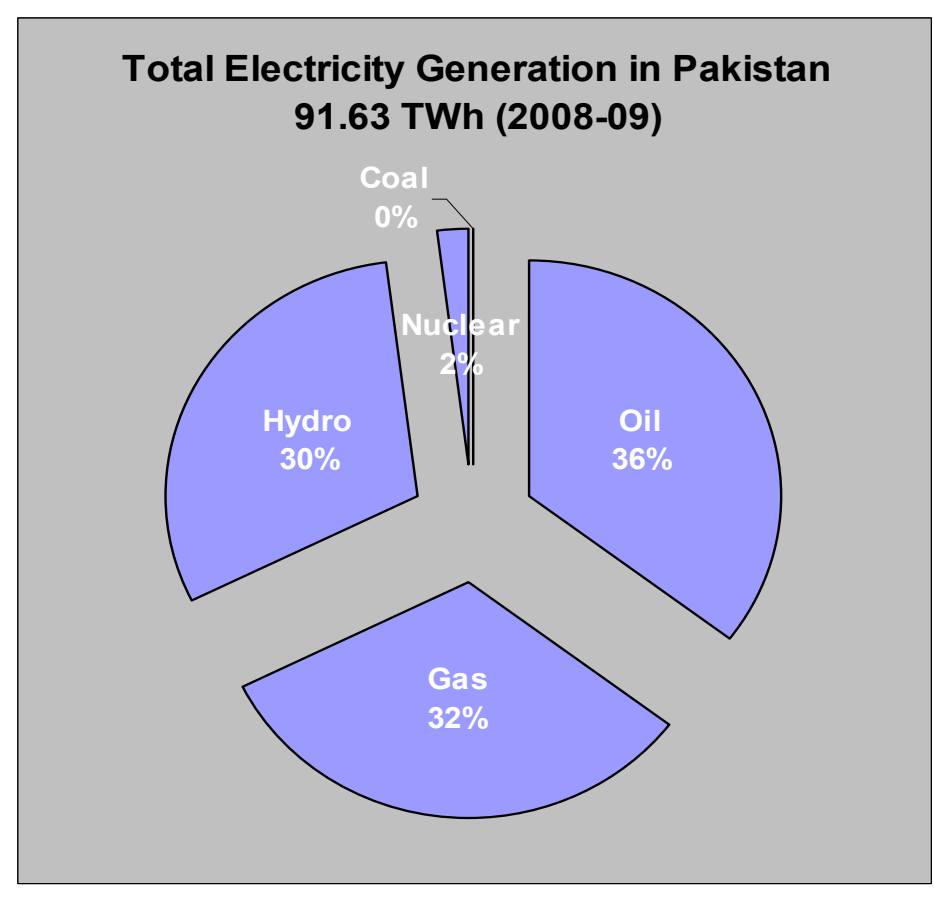

Figure 4. Energy Generation

Data source: Pakistan Energy Year Book, 2009 


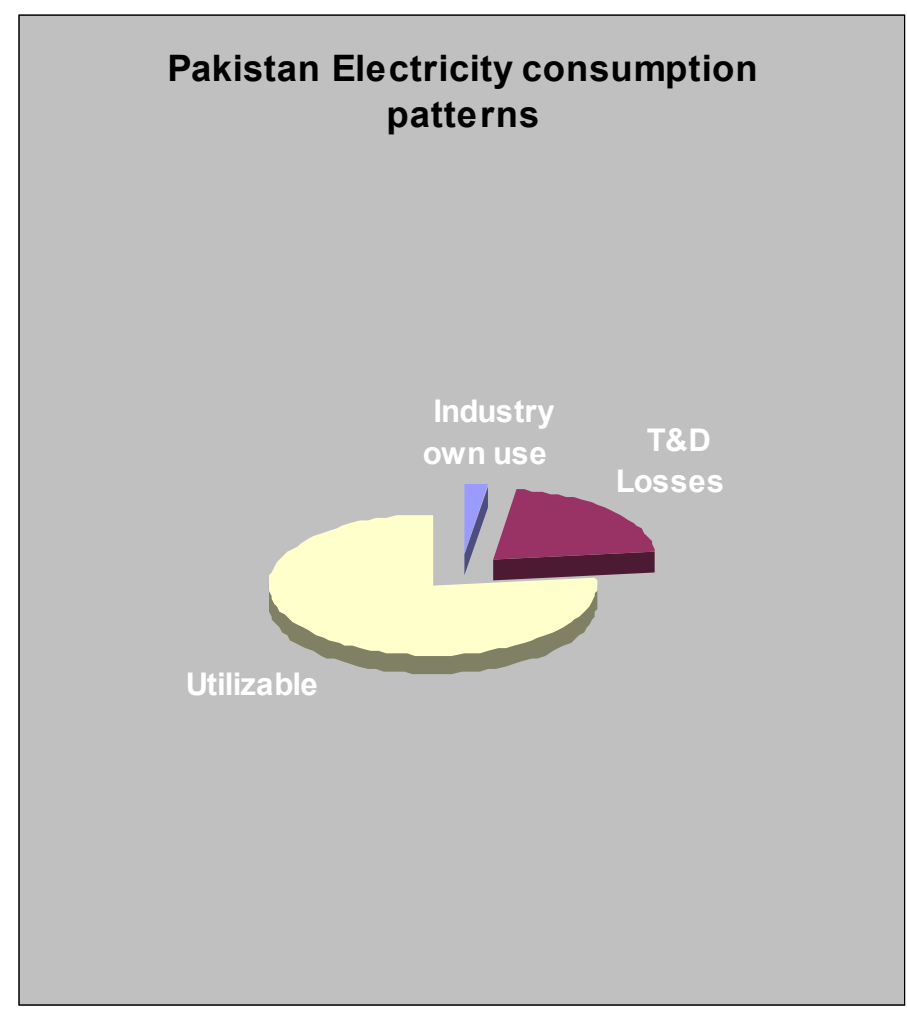

Figure 5. Pakistan Electricity Consumption Patterns

Data source: (Pakistan Energy Year Book, 2009)

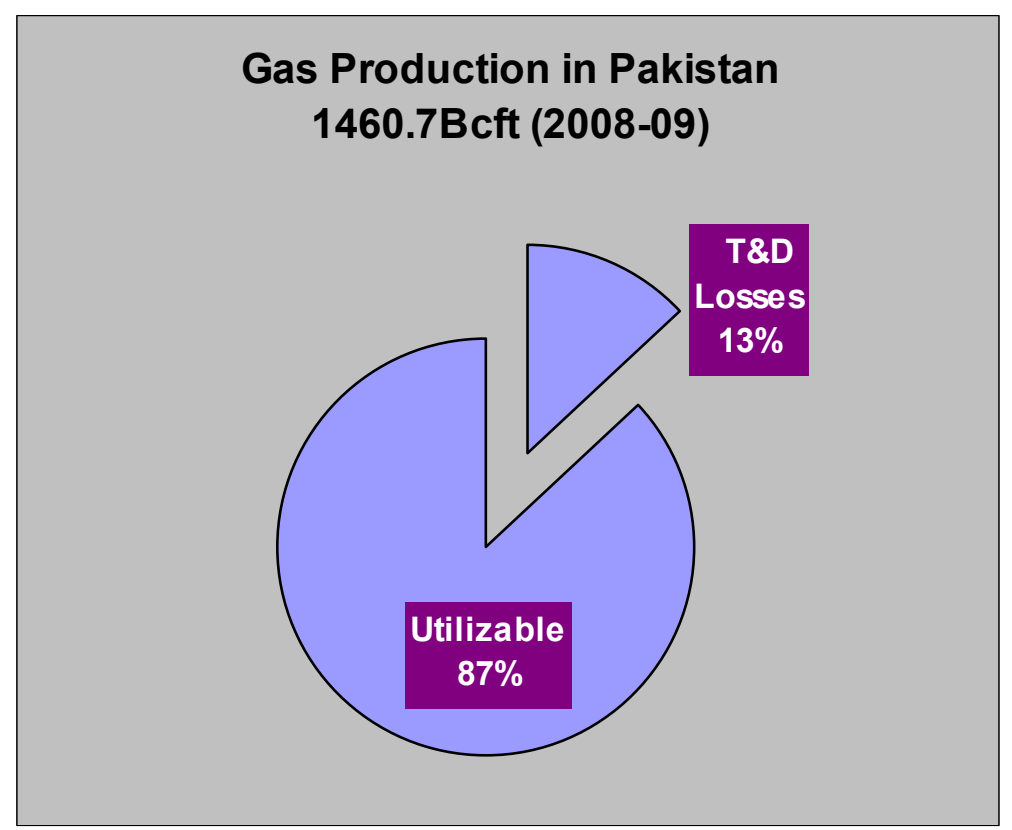

Figure 6. Gas Production in Pakistan

Data source: Pakistan Energy Year Book, 2009 